\title{
215 秋田県小真木鉱山の変質について
}

北海道大学理学部大学院矢島淳 吉

1）北秋田鉱化域の各鉱山については，これまで多く の調査研究が行なわれ，その成果も多数発表されてい る。本鉱山については，榊原 $(1955,1957)$ の調查研究が 女り，特に二次富化現象について詳細な検討が行なわれ た。筆者は主に母岩変質の面から本鉱床を検討し，その 空間的，時間的配置関係を明らかにすることに努めた。

2）地質の詳細はすでに榊原によつて報告されている のでここには省略する(第 1 図参照)。ただ本鉱床に関す るこれまでの報告に扣いて，多く角碟凝灰岩（大葛層） とされているもののほとんどは, 白根坑に扮いて質入岩 体をなしている石英安山岩と全く同質の角䃇からのみな るもので，これを筆者は，角碟化石英安山岩とみなした。 したがつて，本鉱床の母岩は，全体に浪涪均質な石英安 山岩の貫大岩体打よびその角磻化岩とからなる。

3）野外に扣いてその分布や性格が十分確認されてい ないが，本石英安山岩岩体中およびそれを貫く幾つかの 流紋岩小岩脈中に沸石相とみられる変質鉱物組合せが認 められる。変質鉱物は, 沸石(未同定), リストバル石, 緑泥石で，それらが単独に，また幾つかの組合せとなう て産出する。変質は石基中のガラス扣よび長柱状斜長石 の部分から進み，沸石，クリストバ ル石などが自形をとるものも多く， 識別し易い。分布は，鉱化による変 質域の外側にのみ限られ，その内部 には全く見られない(第 1 図参照)。

4）鉱化変質域は平面的には楕円 形に面積的な塘がりを持ら，その範 囲全体に一様な変質鉱物組合せが現 われている。地表に扣いては，肉眼 的には白色化で現わされる。その内 容は, 絹零母一石英一(緑筑石) 組合 せが普掘的である。絹雲母一石英は 鉱化変質を受けていない部分から富 鉱部の上部に向つて，次第にその量 と粒度を增して扮り，強綟霛母一石 英一(緑策石，黄鉄鉣)带は，富鉱部 の上部に，その走向方向に沿つた， ほぼ带状の配列をとつて現われてい る。新鮮な岩相から強絹雲母一石英 带までの変化はすべて漸移的なもの であり，特定の剪断带等で境される そいうような事実は見られない。

地表でみられる以上の如き変質相 子対照的に, 坑内に扮いては，一定 の水準以下に扣いて, 淡嫁色化を伴 了別種の変質鉱物組合せがみられる (第 2 図参照)。これは，緑泥石一綃 雲母一石英一黄鉄鉱一(緑策石) 組合 世で性格づけられるもので, 鉱脈富 鉱部を包みこんで，白根坑準下一番 坑〜下二番坑以下に, 塊状となつて 分布しており地表には全く見られな い。その中を更に分带できるような
特徵的な変化はなく，鉱脈の極く近くに至るまで，範囲 全体にほぼ均質で粒度もほぼー定である。微粒の石英々 その周团をとりまく絹雲母, 緑泥石の葉片状結晶の集合 として見られるが，この絧雲母，緑泥石が鏡下では汪々 んど区別することができず（屈折率，複風折，色等）；両 者一体となつているように見受けられる。X線回折の結

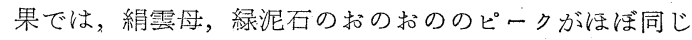
強度で現われ，特に混合層問題や，長周期粘土の存在は 見られないが，なおその点，今後の検討を要する。

地表に広く見られる絹雲母一石英寡の絹雲母は，一般 に淡裪色, dusty で, 坑内に見られる綃零母一緑泥石の clear な結晶片とは対照的でめるが，両者の絹雲母につ いては，現在のところX線的な性質の相異は十分に確か められていない。また，脈石の緑泥石は，色，多色性， 異常干渉色など明瞭で, 絧雲母一緑泥石一石英一黄鉄鉱 帯の緑泥石と対照的であるが，この両者の緑泥石にも， $\mathrm{X}$ 線的な性䨘の相異は認め難い。

以上，二つの大きな変質域は，それぞれ鉱脈の内容に ほぼ対応して拉り, 主要な硫化鉱が沈積している範囲で は，絹雲母一緑泥石一石英一黄鉄鉱一(緑箱石)組合せで

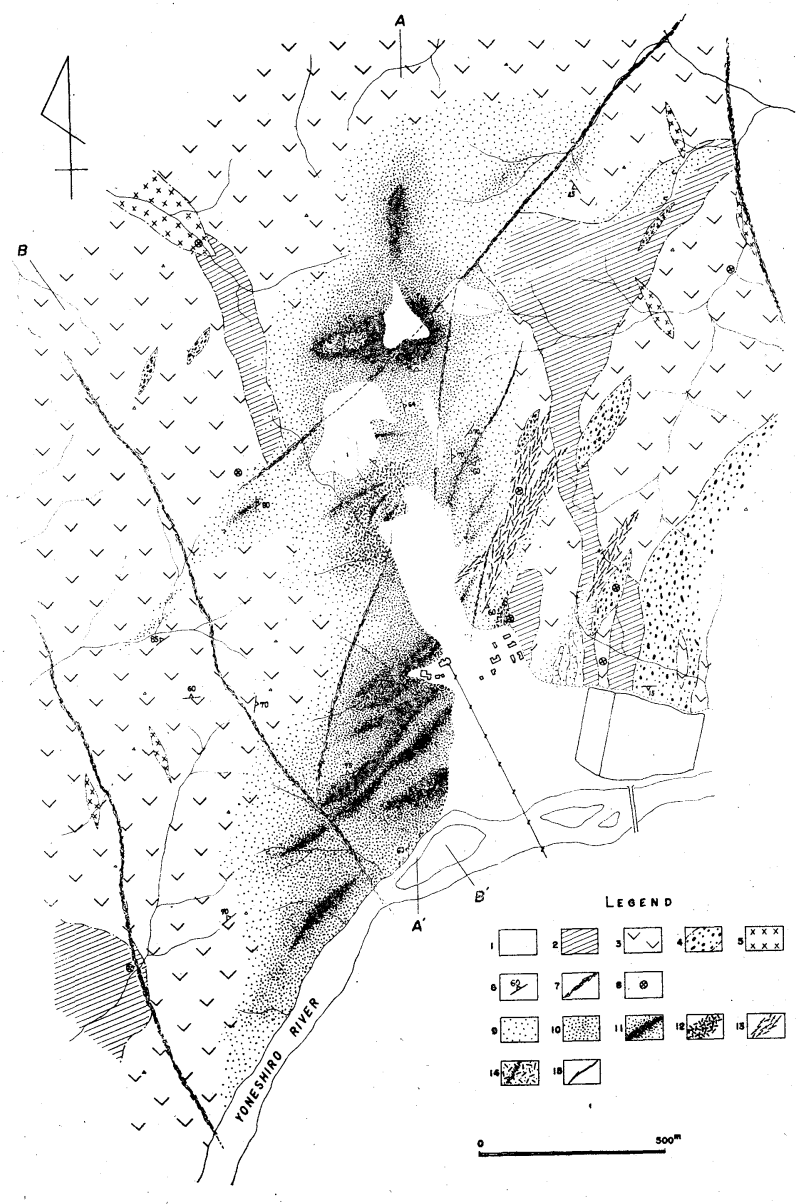

1. 第四紀層

2. 大莀層 (㠜灰 岩, 頁岩)

3. 石英安山将

4. 流紋岩

5. 安山岩

6. 石英安山岩の 流理

7. 剪断带

8. 沸石相産出地 点

9. 弱絹雲母一石 英一(緑策石) 带

10. 絹雲母一石英 一(緑筹石)带

11. 強絹雲母一石 英一黄鉄鉱帯

12. 絧雲母粘土带

13. 緑泥石带

14. 絹雲母一緑泥 石一石英一黄 鉄鉱一 (緑策 石) 带 15. 捈脈

第 1 図 


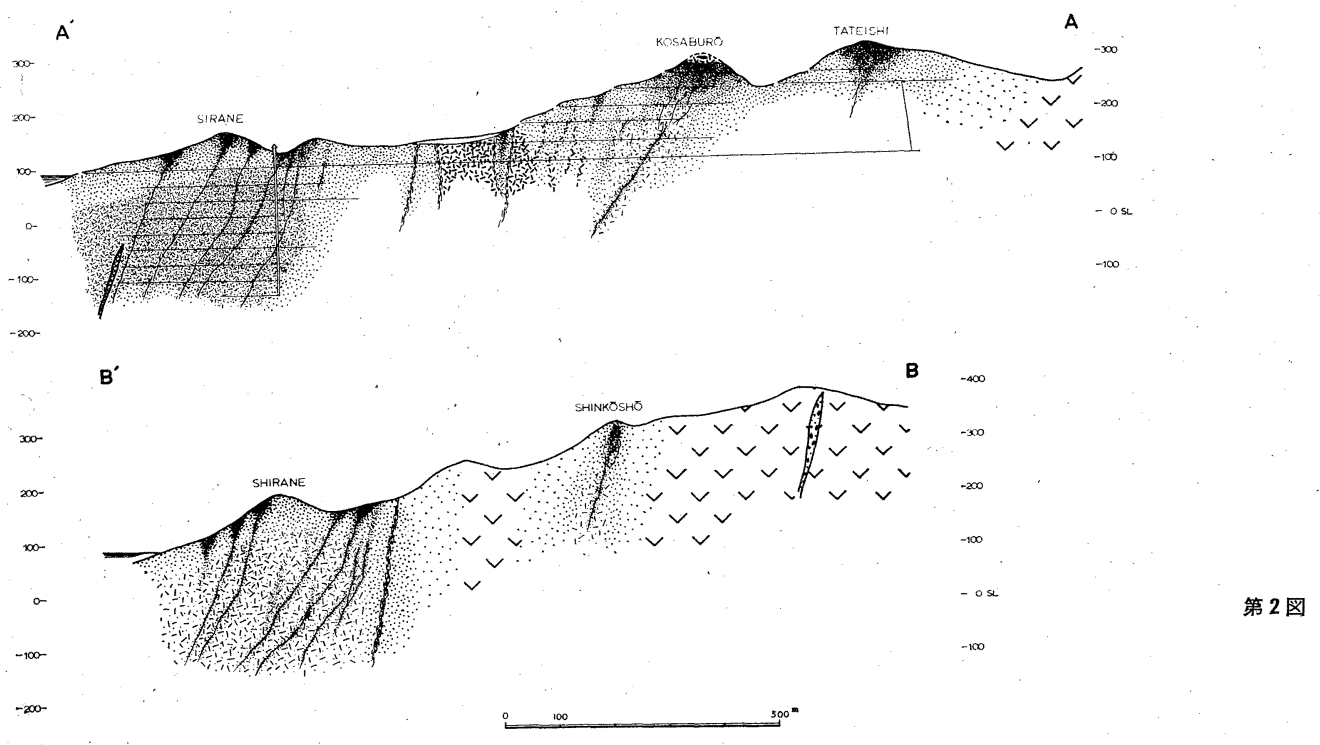

岕り，上部に至り，白色の絹雲母一石英带に扮いて，金， 銀の沈積をみるものである。

かつて黒鉱を産出した小三郎坑周辺に扣いても，黒鉱 鉱床に特有の諸種の变質域はみられず，地表に広く分布
する絹雲母一石英一(緑筹石)組合せと基本的には变りな く, 強絹雲母一石英一黄鉄鉱帯が露天掘跡周辺に円型に 拡がりをみせているのみである。

\section{6 鉱脈の富鉱部形成の $2 ， 3$ の例について}

\section{1. 緒 言}

鉱脈の富鉱部がいわゆる $\mathrm{P} ・ \mathrm{~T}$ 扣よび $\mathrm{pH}$ 以外の条件 によつて形成されたと解される $2 \cdot 3$ の例について述べ る。ここでは神山貞二 ${ }^{3}$ が鉱脈論中で述べている母岩の 不均一性・鉱脈の変曲部・被覆岩および粘土・落合直り などによる富鉱部の形成についてはふれないことにし， 上記の原因でもさらにふえん説明を要する場合や，他の 条件によると解される例にとどめた。

\section{2、富鉱部の形成を規制した条件}

\section{1 裂力と鉱液の不均衡}

鉱脈裂カを鉱液が充買したものであるが，鉱液が上 昇する裂カの急激な形態変化または尖隇した場合富鉱部 を形成した例として大江鉱床 (裂カの鲁尖減), 高玉鉱山 （被覆岩）などの場合がある。

2.1. A 大江鉱床 大江鉱床 ${ }^{4}$ は $\mathrm{N} 60^{\circ} \mathrm{W}$ 方向の平 行脈群よりなつているが，これらの鉱脈は裂っ生成前に 生じた $\mathrm{N}-\mathrm{S}$ 方向の断層部々交わる点で急尖滅して行く 傾向を示し，この裂カが急尖滅する简所に特に繰り返さ れた鉱化作用中の晚期の硫化鉱物が富鉱部を形成してい る。

この現象は早期の鉣液が裂カの主要部を充墤しつく し，晚期の鉱液が上記尖滅部に大量に沈殿したものと解 される。これらの関係を示すと第 1 図のようになる。

2.1. B 高玉鉱床 高玉鉱床の富鉱部の形成について

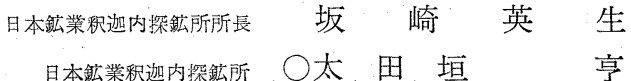

はすでに柳生六郎 (2)が被㠅岩の㗢さとして発表している が，その後さらに開発が進むにつれ，裂かが被覆岩の㗢 きをした頁岩中で細脈化し，かつ不規則状を呈しながら も上部層まで連続する場合（仮に開放裂力と呼ぶ）と裂 カが全く頁岩層を貫き得ないで尖隇して行く場合（仮に 閉鎖裂力と呼ぶ) とがある。

これら両者の富鉱部との関係をみると開放裂力の場合 は富鉣部の上限は漸減形態を示し，閉鎖裂力の場合は富 鉱部の上限がきわめてシャープな形態を示している。こ の現象は裂力と鉱液の不均衡によるものと解される。こ れらの関係を示すと第 2 図のようになる。

\section{2 鉱液の反応変化}

鉱液が $\mathrm{P} ・ T$ および $\mathrm{pH}$ 条件によつて地表より一定の 深さに沈殿することは古くから実証された事实である が，ここでは鈗化作用の先駆活動である変質帯との反応 によつて富鉱部を形成した例として金瓜石鉱床について 述べる。

2.2. $\mathbf{A}$ 金瓜石鉱床 金瓜石鉱床の母岩の変質 ${ }^{5}$ は鉱 化作用の先駆活動として行なわれ上部より珪化・黄鉄鉱 化 $\rightarrow$ 明鐢石化 $\rightarrow$ 粘土化（カオリン群・セリサイト群・ク ロライト群）の順に分布しているが，鉱石鉱物も顕著な 帯状分布を示し上部より $\mathrm{Au}$ 带・ Cu 带と区分でさる。 これら両者の関係をみると $\mathrm{Au}$ 带は明攀石化带の上部よ り珪化带にわたつて分布し, $\mathrm{Cu}$ 帯は粘土化帯中に分布 している。

特に金瓜石鉱体では $\mathrm{Au} \cdot \mathrm{Cu}$ の両鉣脈々も $2 \mathrm{~cm}$ 以下の 